\title{
OTHER ACCEPTED NAMES FOR THE WORKS IN THIS COLLECTION
}

Adam, The Apocalypse of .................................

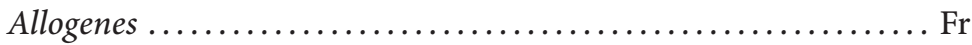

Apocalypse of Adam.....................................

Apocryphon of John, The ............................ BJn

Archons, The Hypostasis of the......................... RR

Archons, The Nature of the ........................... RR

Barbelognostics, The.......................... IrG

Barbēlites, The...$\ldots \ldots \ldots \ldots \ldots \ldots \ldots \ldots \ldots \ldots \ldots \ldots$.EpG

Barbeloites, The $\ldots \ldots \ldots \ldots \ldots \ldots \ldots \ldots \ldots \ldots \ldots \ldots \ldots$ IrG

Basilides. Frag. 2, ed. Völker ........................ BasFrG

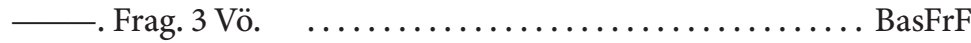

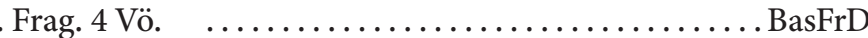

Basilides' Myth .............................. IrBas

Book of Thomas the Athlete (Contender)

Writing to the Perfect, The .......................... BTh

Borborites, The.$\ldots \ldots \ldots \ldots \ldots \ldots \ldots \ldots \ldots \ldots \ldots \ldots \ldots$. EpG

Colophon to NHC (or CG) I, so-called . ............... PP1

Corpus Hermeticum $1 . \ldots \ldots \ldots \ldots \ldots$. . . . . . . . . .

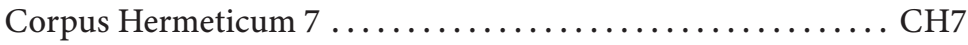


Egyptians, The Gospel of the ........................ EgG

Epistle to Rheginus on Resurrection, The .................. TRs

Gospel of the Egyptians, The ........................ EgG

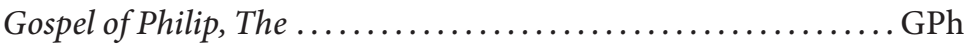

Gospel of Thomas, The ............................GTh

Gospel of Truth, The (as anonymous work) $\ldots \ldots \ldots \ldots \ldots \ldots$ GTr

Hermetic Corpus, Tractate $1 \ldots \ldots \ldots \ldots \ldots \ldots \ldots$.......... Poim

Hermetic Corpus, Tractate $7 \ldots \ldots \ldots \ldots \ldots \ldots \ldots \ldots$ CH7

Hymn of Jude (Judas) Thomas the Apostle in the Country

of the Indians, The .................................

Hymn of the Soul, The................................Prl

Hypostasis of the Archons, The........................ RR

Invisible Spirit, The Holy Book of the Great ............... EgG

John, The Apocryphon of ........................... BJn

Jung Codex, Colophon (so-called) $\ldots \ldots \ldots \ldots \ldots \ldots \ldots \ldots$ PP1

Letter to Rheginus, The........................... TRs

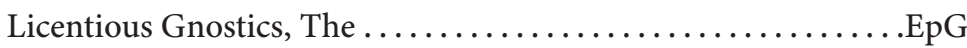

Logia Iēsou, The ..................................

Nature of the Archons, The .......................... RR

Philip, The Gospel of ................................

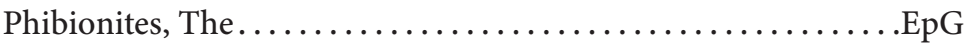

Pimander........................................ Poim

Prayer of the Apostle Paul, The .......................... PPl

Rheginus, The Epistle (or Letter) to ................... TRs 
Rulers, The Nature of the RR

Satornilos (or Satornil) IrSat

Seth, The Three Steles of. $.3 \mathrm{~Tb}$

Stratiōtics, The EpG

Thomas, The Gospel of . GTh

Thomas the Contender (Athlete), The Book of BTh

Three Steles of Seth, The. . $.3 \mathrm{~Tb}$

Thunder, Perfect Mind Th

Trimorphic Protennoia, The. FTh

Triple Protennoia, The FTh

Valentinus. Harvest. $\mathrm{VHr}$ Frag. 1, ed. Völker .VFrC Frag. 2 Vö. .VFrH Frag. 3 Vö. VFrE . Frag. 4 Vö. VFrF

—. Frag. 5 Vö. VFrD

—. Frag. 6 Vö .VFrG

- Frag. 7 Vö. VFrA Frag. 8 Vö. .VHr

- Frag. 9 Vö. VFrB 
This page intentionally left blank 